\title{
6.9 Особливості моделювання художньо-виконавської техніки музиканта
}

На сучасному етапі розвитку музичного мистецтва вагомості набувають процеси свідомого, системного формування художньо-виконавської техніки музиканта на грунті урахування індивідуально-психологічних рис особистості майбутнього артиста. Зважаючи на специфіку музичного мистецтва, формування виконавського процесу вимагає дослідження його діалектичної суті взаємозв'язку раціонального та ірраціонального. Таке розуміння становлення музиканта-фахівця спонукає до осмислення виконавського мистецтва як особистісно-фахового феномену та пошуку регулятивної (гнучкої) методики його формування. Центральною ланкою виконавської техніки є формування виконавських умінь музиканта, через які відбувається віддзеркалення особистісного у процесі виконання музичного твору. 3 іншого боку, через виконавські уміння музикант виявляє сутність, розкриває фабулу музичного твору. В самому понятті виконавської техніки музиканта сублімується індивідуальне та загальне, особистісне та соціальне, естетичне та вузько спеціалізоване. Власне виконавська техніка музиканта представляє суб’єктоб'єктний взаємозв'язок у процесі інтерпретації музичного твору $[458$, с. 2]. Отже, художньо-виконавська техніка $є$ поєднанням індивідуальноособистісного та фахово-спеціалізованого у процесі роботи над музичним твором, що вимагає напрацювання, розробки особистісно-фахової методики моделювання даного феномену, яка має враховувати, розвивати i удосконалювати індивідуально-особистісні якості музиканта-виконавця та специфіку його фахового становлення. Оскільки основним завданням музиканта-виконавця $€$ розкриття змісту музичного твору через доцільно дібрані технічні засоби виразності, важливим є здійснити диференціацію виконавської техніки інструменталіста, охарактеризувати кожен 3 видів виконавського уміння та визначити перспективні методи їх формування .

Проблемам якісного формування виконавської техніки музиканта присвячено велику кількість джерел, аналіз яких спонукає до визначення 
кардинальних напрямків розвитку даного феномену. Більшість науковцівмузикантів вбачають доцільність розвитку техніки музиканта-виконавця через вузькоспеціалізоване опанування технічними виконавськими прийомами [460]. Низка праць з методики опанування гри на інструменті пов’язується з процесом становлення музиканта-виконавця, грунтованого на аналізі фізіологічних та психологічних особливостей самої особистості музиканта [461]. На сучасному етапі розвитку художньо-виконавської техніки музиканта домінантності набувають креативно-регулятивні процеси формування професіоналізму через розвиток індивідуальних якостей та особистісних властивостей музиканта [ 462].

Мета статті полягає у розкритті сутності та структури художньовиконавської техніки музиканта, а також представленні інноваційної методики iii моделювання. Поставлена мета вимагає вирішення таких завдань: визначення сутності та структури художньо-виконавської техніки музиканта; здійснення характеристики пріоритетних методів моделювання художньо-виконавської техніки музиканта; дослідження специфіки формування художньо-виконавської техніки музиканта в процесі інтерпретації музичного твору.

У зв'язку, з цим у контексті фахової діяльності музиканта-виконавця домінантності набувають процеси застосування механізмів саморегуляції самопізнання, самоставлення та самокорекції. Саме розвиток музичновиконавських умінь на основі застосування методики саморегуляції в процесі опанування гри на інструменті сприяє постійному удосконаленню музичновиконавської діяльності і формує музичне виконавство як мистецтво [462].

Художньо-виконавська техніка музиканта є сукупністю засобів технічної виразності музиканта-інструменталіста, спрямованих на інтерпретацію змісту музичного твору. Виконавська інтерпретація представляє собою процес емоційно-інтелектуального осягнення музичного твору артистом, який здатний зрозуміти думку композитора, пережити та передати іiі слухачеві через індивідуальну систему технічних прийомів та музично-асоціативних образів. У 
зв’язку з цим, до структури виконавської техніки музиканта входять технічнодоцільні та художньо-інтерпретаційні уміння [463, с. 7].

До технічно-доцільних умінь відносимо технічні прийоми музикантаінструменталіста, сформовані на грунті усвідомленої взаємокоординації слухорухових та образно-рухових відчуттів. Все це складає процес розвитку сенсомоторики музиканта-інструменталіста. Наприклад, формування штрихової техніки інструменталіста, досягнення різнодинамічного звукоутворення на інструменті здійснюється на основі аналізу м’язового відчуття (стану) різноманітних рухових форм плеча, передпліччя, кисті та пальців у професійних рухах виконавця. Тобто, технічні прийоми музиканта-інструменталіста формуються через відчуття доцільного м'язового стану та через усвідомлення картини руху рук у надбанні технічних умінь. Отже, критерієм сформованості доцільного, якісного розвитку технічно-доцільних умінь музикантаінструменталіста є свідоме володіння та регуляція аналізом м'язового відчуття в процесі становлення технічних умінь, знання механіки та динаміки професійних рухів та усвідомлене їх застосування через регулятивні методи в процесі розвитку виконавської техніки музиканта.

Художньо-інтерпретаційні уміння можна трактувати як спосіб вимовлення музичної тканини твору, що інтерпретується, через відповідний добір технічно-доцільних прийомів інструменталіста. В основі побудови інтерпретації музичного твору є процес моделювання виконавської артикулящї. Виконавську артикуляцію можна розглядати як інструментальнотекстове вимовлення музичного твору засобами технічної виразності музиканта. Критерієм сформованості художньо-інтерпретаційних умінь $є$ свідоме володіння та регуляція темпоритмічною (агогічною), динамічною, тембральноштриховою та цезурною артикуляціями. Формування художньоінтерпретаційних умінь обумовлюється сформованістю технічно-доцільних умінь, оскільки інтерпретаційний процес музичного твору передбачає свідоме, регулятивне застосування системи засобів технічної виразності в роботі над розкриттям змісту музичного твору. Застосування того чи іншого виду 
виконавської артикуляції здійснюється виконавцем згідно його індивідуальної образно-асоціативної системи. Багатство, насиченість, неординарність, різноплановість, глибина даної індивідуальної системи спонукає до творчого застосування технічних прийомів, художньо обгрунтованих в процесі роботи над музичним твором.

Формування всіх видів виконавської артикуляції пов’язані з регулятивними механізмами, що свідомо поєднують у виконавському умінні слух, образ, рух для творення виконавського внутрішнього музичного образу. Крім цього, вся система артикуляції моделюється у полі інтерпретації музичного твору, згідно зі стилем та змістовним наповненням - фабулою музичного твору. Наприклад, у інструментальних барокових творах добір динамічної артикуляції, яка часто тут $€$ контрастною, грунтується на основі сенсомоторної саморегуляції м'язового відчуття у процесі звуковидобування у раптовому межуванні динаміки форте та піано. Ця контрастна динаміка у струнно-смичковій техніці кардинально відрізняється за принципом виконання у формах руху та м'язовому відчутті. Миттєва корекція, здатність до регуляції доцільних рухів та м'язових відчуттів $є$ основою еластичності, художності та естетичності динамічних відтінків у музикантів-інструменталістів.

Моделювання агогічної - темпоритмічної артикуляції у романтичному репертуарі, наприклад виконавця-струнника, вимагає тонкого володіння різноманітною швидкістю ведення смичка та відповідного натиску руки на нього. Темпові пришвидшення та заповільнення у грі на інструменті пов'язані 3 умінням використовувати різні м'язові стани - напруження та розслаблення, а також їх застосування у різних часово-темпових комбінаціях. Отже, свідоме напрацювання технічних умінь на грунті аналізу м'язового відчуття формує, в першу чергу, доцільний технічний прийом, а далі зумовлює його удосконалення чи трансформацію в процесі інтерпретації змісту музичного твору.

Важливим у процесі роботи над музичним твором є добір тембральноштрихової виконавської артикуляції. Цей вид артикуляції поєднує в собі застосування доцільних технічних прийомів виконавця-інструменталіста - 
звуковидобування, штрихів, аплікатури, вібрації відповідно до виконавських асоціативних образів, уяви та емоційного переживання змісту музичного твору. Тут особливої домінантності набувають процеси налагодження координації слуху, уяви та добору технічного прийому, в роботі над музичним твором, що власне $\epsilon$ основою формування художньо-інтерпретаційного уміння. Таким чином, дуже важливим у роботі над музичним твором $\epsilon$ формування індивідуального асоціативного образу, розвиток внутрішньої асоціативнообразної виконавської системи, яка в подальшому може видозмінюватися, регулюватися відповідно до асоціативно-образної системи фабули музичного твору.

Цезурна виконавська артикуляція $є$ системою розділових знаків у відтворенні музичного тексту, своєрідного показу розгортання - початку та закінчення музичної фрази, періоду, речення. Її можна вирізнити як контекстну ma підтекстову. Контекстна цүезурна артикуляція та, яка зображена композитором у нотному тексті і охоплює різноманітні позначки пауз, цезур, фермат. Підтекстова, або сюжетна артикуляція та, яка індивідуально відчитується, відтворюється виконавцем. Вона може збігатися або не збігатися 3 контекстною артикуляцією, тобто в різній мірі ( довгі фермати, короткі цезури) відтворюватися інструменталістом. У даному випадку це пов'язується зі змістовним розумінням виконавцем музичного твору, 3 індивідуальним способом фразування, зі специфічністю побудови архітектоніки виконання. Також сформованість даної артикулятивної системи пов'язується з контролем за диханням, як фізіологічної основи доцільного технічного прийому ( контроль дихання у процесі виконання різномантіних штрихів, вібрації тощо), так i художньої основи - показу тривалості, уривчастості дихання в залежності від характеру вимовлення музичної фрази, показу ( представлення) спаду чи кульмінації у частині твору.

Важливого значення у процесі формування художньо-виконавської техніки музиканта посідає формування сценічно-стабільного виконання твору музикантом як складової успішної презентації інтерпретації змісту музичної 
твору. Тут слід підкреслити, що виконання твору на сцені набуває стабільності за умови сформованої виконавської моделі інтерпретації. При сценічному виконанні необхідно слідкувати за - наперед продуманою виконавцем логікою розгортання переживань змісту музичного твору, та, згідно цього, контролювати якість виконання доцільно обраних технічних умінь.

У зв’язку з цим, важливого значення у становленні художньо-виконавської техніки музиканта набуває застосування методики моделювання програми саморегуляції виконавських умінь музиканта .

Методику саморегуляції музиканта-інструменталіста умовно можна розподілити на абстрактну ( загальну) - на грунті якої формуються технічнодоиільні виконавські уміння та предметну, що складає основу моделювання художньо-інтерпретачійних умінь.

Під абстрактною саморегуляцією розуміємо уміння музиканта-виконавця адаптувати власні технічні прийоми, згідно різноманітних завдань, не пов'язаних з інтерпретацією музичного твору. Серед основних таких завдань необхідно визначити основні.

В першу чергу, це здатність визначити, проаналізувати та відтворити найцінніший для виконавця технічний прийом гри. Визначити підгрунтя цінності даного технічного прийому - чи він найкраще технічно виходить у виконавця, чи має відповідну емоційно-образну характеристику, що консеквентна його особистісній духовно-ментальній сфері.

Далі, з'ясувати технічні відмінності виконання різноманітних форм технічний прийомів інструменталістів. Наприклад, з'ясувати відмінності виконання на інструменті штриха деташе - барокового, романтичного та декламаційного. Або штриха спіккато, який у виконавській техніці розрізняється за характеристиками як віртуозний так і драматичний прийом.

Важливим $є$ для виконавця вміти показати різноманітні інструментальні тембри, барви, колористику на інструменті та з'ясувати, проаналізувати їх взаємозв'язок, взаємозалежність з специфікою виконання технічних прийомів музиканта. Це зумовлює формування художньо-асоціативної техніки музиканта. 
Також до абстрактної саморегуляції можна віднести уміння регулювати добирати, комбінувати, творити засоби технічної виразності у відповідності до індивідуально-домінантної асоціативно-образної сфери музиканта-виконавця. Для цього застосовуються завдання, пов'язані 3 відтворенням у грі на інструменті власного найціннішого, улюбленого образу - природи, запаху квітки, найулюбленішого відчуття ( радість, сум...), найближчої людини. В даній ситуації опановується процес еластичної спрямованості власних технічних умінь на відтворення індивідуального уявного образу. Таким чином здійснюється інструментальна візуалізація образу .

Предметна або програмна саморегуляція - це, так звана, програмна саморегуляція виконавської техніки скрипаля у процесі інтерпретації музичного твору. Відмінність даної саморегуляції полягає в тому, що вона повинна бути конкретно спрямована на представлення власного професіоналізму виконавця в конкретно визначених композиції та драматургії музичного твору. Тобто, виконавська техніка має застосовуватися як система артикулятивних засобів, що розкриває інтонаційно-образну систему музичного твору. На грунті цього формується уміння саморегулювати суб'єктивне виконавське розуміння змісту та добирання інструментальної техніки в полі об’єктивного композиторськообразного континууму музичного твору.

Процес інтерпретації фабули музичного твору грунтується на предметній (програмній) музично-виконавській саморегуляції. В даному контексті необхідно застосовувати рефлексивні, креативні та корективні методи.

В основі рефлексивних методів лежить процес самопізнання як один із механізмів фахового самоусвідомлення. Даний процес грунтується на двох завданнях. Перше завдання полягає у визначенні виконавцем домінантного образу музичного твору, над яким ведеться робота та визначенні найбільш характеристичних композиторських прийомів його представлення. Це означає необхідність пізнання виконавцем композиційної та сюжетної ( драматургічної) форми музичного твору. Другим завданням рефлексивної методики $є$ процес визначення власного виконавського слухо-асоціативного образу музичного 
твору та індивідуальний підхід до його технічного, сенсомоторного відтворення.

Засадним у креативній методиці $є$ процес самопорівняння, творення самооцінки. Даний процес передбачає самоосмислення, самооцінку, самопорівняння доцільності власних слухо-асоціативних уявлень та засобів їх технічного відтворення в процесі роботи над музичним твором. Сутністю даної методики $€$ порівняння власного сприйняття твору з особливостями його композиторського представлення, з його стильовою специфікою. 3 цією метою, на першому етапі креативної методики пропонується застосовувати здійснення виконавсько-порівняльного аналізу твору різними еталонними виконавцями. На другому етапі виконавець здійснює самоосмислення, самопорівняння, самооцінку власного виконання даного твору 3 проаналізованими на першому етапі еталонними виконаннями. Здійснюється даний креативний самоаналіз на першому та на другому етапі на основі використання відповідних критеріїв: емоційність - ситуативна чи контекстна; технічність - абстрактна чи естетична (художня); виконавські новації - репродуктивні (наслідувальні) чи творчі.

Підгрунтям корективних методів $\epsilon$ уточнення, видозміна та програмування особистісно-виконавського уявлення, згідно 3 фабулою ( драматургією ) музичного твору, а також координація, добір відповідних засобів технічної виразності. Корекція образно-асоціативного уявлення віддзеркалюється на доборі засобів технічної виразності. Відбувається корекція - наближення виконавського домінантного асоціативного образу музичного твору до композиторського, а відповідно до корекції образної уяви коректується, видозмінюється сенсомоторне, асоціативно-технічне іiї представлення в межах індивідуальної фахової майстерності музиканта-виконавця. Даний процес не означає нівелювання індивідуального сприйняття домінантного композиторського образу музичного твору виконавцем. Він спонукає до пошуку різновидностей власного індивідуального, а не постійного збереження самостереотипу - індивідуальної стереотипності артиста. Тим самим, весь процес саморегуляції в загальному спрямований на пошук різноманітного 
індивідуального самовиявлення виконавця, до його творчої адаптації у процесі інтерпретації музичних творів різних стилів та авторів.

Даний процес не означає нівелювання індивідуального сприйняття домінантного композиторського образу музичного твору виконавцем. Він спонукає до пошуку різновидностей власного розуміння змісту музичного твору та його художньо-технічного представлення, що, у свою чергу, уможливлює трансформацію індивідуального виконавського стереотипу артиста. Тим самим, весь процес саморегуляції в загальному спрямований на пошук різноманітного індивідуального самовиявлення виконавця, до його творчої адаптації у процесі інтерпретації музичних творів різних стилів та авторів.

Застосування у процесі моделювання художньо-виконавської техніки музиканта механізмів саморегуляції, зумовлює сценічно стабільну демонстрацію усвідомленої, цілісної, системно сформованої виконавської інтерпретації на рівні інструментальної майстерності. Все це в підсумку спонукає до формування художньо-виконавської техніки музиканта як естетичного, мистецького феномену. 